Article

\title{
Laccase-Catalyzed Oxidation of Allylbenzene Derivatives: Towards a Green Equivalent of Ozonolysis
}

\author{
Mathilde Lecourt $^{1}\left(\mathbb{D}\right.$, Giorgiana Chietera ${ }^{2}$, Bernard Blerot $^{2}$ and Sylvain Antoniotti ${ }^{1, *(\mathbb{C}}$ \\ 1 Institut de Chimie de Nice, Université Côte d'Azur, CNRS, Parc Valrose, CEDEX 2, 06108 Nice, France; \\ mathilde.lecourt@univ-cotedazur.fr \\ 2 LMR Naturals by IFF, Parc d'Activité les Bois de Grasse, 18 Avenue Joseph Honoré Isnard, \\ 06130 Grasse, France; Giorgiana.CHIETERA@IFF.com (G.C.); bernard.blerot@iff.com (B.B.) \\ * Correspondence: sylvain.antoniotti@univ-cotedazur.fr
}

Citation: Lecourt, M.; Chietera, G.;

Blerot, B.; Antoniotti, S.

Laccase-Catalyzed Oxidation of Allylbenzene Derivatives: Towards a Green Equivalent of Ozonolysis. Molecules 2021, 26, 6053. https:// doi.org/10.3390/molecules26196053

Academic Editor: Gonzalo de Gonzalo

Received: 16 September 2021

Accepted: 1 October 2021

Published: 6 October 2021

Publisher's Note: MDPI stays neutra with regard to jurisdictional claims in published maps and institutional affiliations.

\begin{abstract}
Laccase-based biocatalytic reactions have been tested with and without mediators and optimized in the oxidation of allylbenzene derivatives, such as methyl eugenol taken as a model substrate. The reaction primarily consisted in the hydroxylation of the propenyl side chain, either upon isomerization of the double bond or not. Two pathways were then observed; oxidation of both allylic alcohol intermediates could either lead to the corresponding $\alpha, \beta$-unsaturated carbonyl compound, or the corresponding benzaldehyde derivative by oxidative cleavage. Such a process constitutes a green equivalent of ozonolysis or other dangerous or waste-generating oxidation reactions. The conversion rate was sensitive to the substitution patterns of the benzenic ring and subsequent electronic effects.
\end{abstract}

Keywords: biocatalysis; sustainability; phenylpropanoids

\section{Introduction}

Oxidation processes in organic chemistry are typically waste-generating processes [1,2] Not only that the fundamental principles of oxidation of organic substrates require a stoichiometric electron acceptor, but that suitable redox potentials to make these transformations efficient have led to the massive use of metallic oxides eventually leaving metallic by-products. In order to mitigate this undesired effect, combinations of catalytic systems with benign terminal oxidants, such as molecular oxygen [3], hydrogen hydroperoxide [4] or bleach [5], have been developed. This is what Nature does for millions of years with enzymes evolved to achieve specific, selective, and efficient oxidation reactions of organic substrates using indeed $\mathrm{O}_{2}$ or $\mathrm{H}_{2} \mathrm{O}_{2}$ to activate metal centers (mostly $\mathrm{Cu}, \mathrm{Fe}, \mathrm{Mn} \ldots$ ) within their active sites. It is thus tempting to use these enzymes to perform oxidation reactions at laboratory or pilot and full-industrial scale in biocatalytic processes $[6,7]$.

Biocatalysis is a branch of catalysis involving enzymes or cells as catalysts for a given reaction. Biocatalytic processes tolerate mild operating conditions (temperature, $\mathrm{pH}$, pressure) and can be run in aqueous mediums as far as the substrate has sufficient solubility [8]. Enzymes can also be directly used in vivo by applying wild or engineered cells to the substrate $[9,10]$. Besides that, enzymes display selectivity and/or specificity that are of great interest either in fine chemical synthesis or in pharmaceutical or perfumery areas [9,11-13]. Engineered enzymes are more and more often used in industry to replace late steps in a chemical synthesis where high degrees of selectivity and efficiency are required and/or to improve the processes' sustainability [14-16].

Laccases belong to the large oxidoreductase class. This family of enzymes can genuinely convert a wide range of compounds, which can be broadened by using mediators for oxidation transfer $[14,15,17,18]$. Laccases were investigated on various substrates such as phenols, methoxybenzenes, alkenes and polycyclic aromatic hydrocarbons [19-22]. 
These enzymes are employed for lignin degradation in Kraft pulp [23-25] and in phenol depolluting processes $[26,27]$ and are broadly considered in green oxidation catalytic systems $[14,15,28]$.

Methyl eugenol $\mathbf{1}$ is an allylbenzene derivative naturally produced by plants. It was identified as a product of lignin degradation in the presence of laccase from Trametes versicolor and methyl syringate as natural mediators [29]. As $\mathbf{1}$ is an allergen and a carcinogenic agent [30-32]. It is strongly regulated in food and cosmetics [33-35]. Its metabolization by microorganisms involves cytochrome P450, which is an oxidase [36,37]. Its antifungal and cytotoxic effects were also investigated $[38,39]$.

Laccase has been already investigated in the oxidation of phenols, such as eugenol and isoeugenol, and was shown to induce oxidative dimerization $[40,41]$. To our knowledge, laccase-catalyzed oxidation of $\mathbf{1}$ and allylbenzene derivatives has never been studied. Herein, we investigated the activity of laccases on allylbenzene derivatives, including $\mathbf{1}$, in a quest for alternative sustainable oxidative protocols. Intermediates and products were thus isolated, identified and engaged separately in order to better understand the mechanism of the reaction (Figure 1).
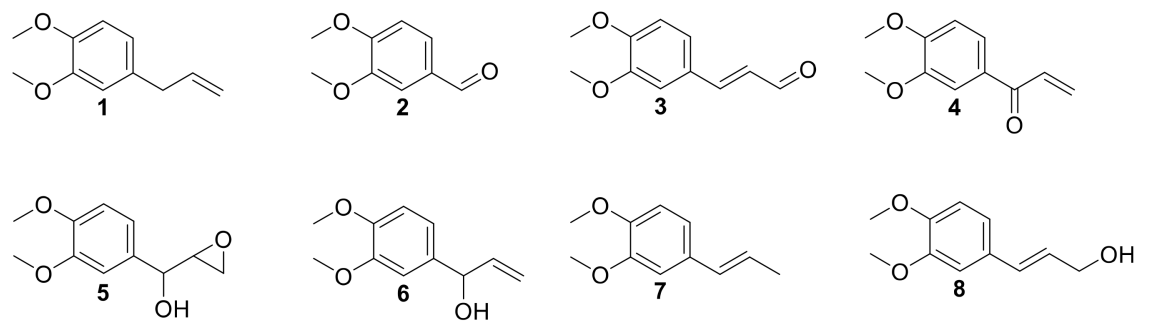

Figure 1. Methyl eugenol 1 and derivatives.

\section{Materials and Methods}

Chemicals: Chemicals, organic solvents and laccase from Trametes versicolor were purchased from Sigma-Aldrich (Saint-Louis, MO, USA) and used as received. Distilled water was obtained by filtration on an Elix ${ }^{\circledR}$ Reference 3 system with a Progard ${ }^{\circledR} \mathrm{S} 2$ cartridge. Laccase M120 was obtained as a kind loan from Amano Enzyme Inc. (United Kingdom), and laccase Mrs was provided by ISM2 Laboratory, France (Pierre Rousselot Pailley, Thierry Tron, Equipe Biosciences), obtained after heterologous expression and purification. Both were stored at $-18^{\circ} \mathrm{C}$.

Analysis: ${ }^{1} \mathrm{H}$ and ${ }^{13} \mathrm{C}$ NMR spectra were recorded on Bruker Avance 400 spectrometer. Chemical shifts, reported in ppm, were referenced relatively to TMS on the signals of residual solvents $\left({ }^{1} \mathrm{H}\right.$ and $\left.{ }^{13} \mathrm{C}\right)$. GC/MS analyses were carried out with an Agilent 7820A chromatograph coupled to an Agilent 5977B MS detector (Agilent, California). Samples were analyzed on a capillary column SAPIENS-5MS $(10 \mathrm{~m} \times 0.10 \mathrm{~mm} \times 0.10 \mu \mathrm{m}, 5 \%$ diphenyl-95\% dimethylpolysiloxane, Teknokroma, Spain). Operating conditions: carrier gas: $\mathrm{He}$, constant flow, $20 \mathrm{~mL} / \mathrm{min}$; injection temp., $250^{\circ} \mathrm{C}$, injection volume, $0.2 \mu \mathrm{L}$, split ratio, 1:50; temp. program: $50{ }^{\circ} \mathrm{C}$ held $1 \mathrm{~min}, 50{ }^{\circ} \mathrm{C}$ to $280{ }^{\circ} \mathrm{C}$ at $10{ }^{\circ} \mathrm{C} / \mathrm{min}$, then held isothermal (10 $\mathrm{min})$, ion source temp., $230^{\circ} \mathrm{C}$; transfer line temp., $300^{\circ} \mathrm{C}$; ionization energy, $70 \mathrm{eV}$; electron ionization mass spectra were acquired over the mass range of 35-550 amu.

Identification of the products was based on comparison of their MS spectra with those of commercial libraries (NIST15, Wiley), laboratory MS libraries built up from pure substances, with MS literature data, or comparison with authentic samples.

Standard procedure for the enzymatic oxidation of allylbenzene derivatives: Substrate $(1 \mathrm{mmol}, 0.25 \mathrm{M})$, mediator ( $10 \mathrm{~mol} \%$ ) and laccase $(5 \mathrm{wt} \%)$ were introduced in a $20 \mathrm{~mL}$ vial in a pH5 $20 \mathrm{mM}$ aqueous acetate buffer $(4 \mathrm{~mL})$. The reaction medium was incubated under an oxygen atmosphere using an incubator shaker with orbital agitation $\left(24 \mathrm{~h}, 40^{\circ} \mathrm{C}, 200 \mathrm{rpm}\right)$. The work-up consisted of EtOAc extraction of the aqueous phase $(5 \times 2 \mathrm{~mL})$. Organic phases were pooled, dried over $\mathrm{MgSO}_{4}$ and concentrated in vacuo. GC/MS and ${ }^{1} \mathrm{H}-\mathrm{NMR}$ 
were performed to determine the reaction outcome on crude products during optimization phases and on purified material after column chromatography for synthetic purposes.

Oxidation intermediates characterization: Enzymatic oxidation was carried out on a larger scale. ME 1 (11.96 mmol, $0.1 \mathrm{M})$, HOBt (1.23 mmol, $166.8 \mathrm{mg}$ ) and laccase (46 mg) were dissolved in a pH5 $20 \mathrm{mM}$ aqueous acetate buffer $(120 \mathrm{~mL})$. The mixture was stirred under an oxygen atmosphere in an oil bath at $40{ }^{\circ} \mathrm{C}$. After $24 \mathrm{~h}, 1 \mathrm{~mL}$ of the mixture was submitted to the above-described work-up, and the reaction progress was estimated by GC/MS analysis. In the case of partial conversion, an addition of laccase and mediator was performed (up to 8 additions for a total of $1292.3 \mathrm{mg}$ of HOBt and $349.3 \mathrm{mg}$ of laccase). Upon the completion of the reaction with full conversion, the work-up was performed as described. Different products were isolated by column chromatography on silica gel (diethyl ether/petroleum ether gradient as the eluent).

Compounds 1, 2 and 7 were purchased from Sigma-Aldrich (Saint-Louis, MO, USA), and compound 3 was purchased from Enamine (Ukraine).

(3,4-Dimethoxyphenyl)prop-2-en-1-one 4: 6 (2.61 mmol) was diluted in EtOAc (0.12 M). Manganese oxide $\left(\mathrm{MnO}_{2}, 4.16\right.$ eq. $)$ was added, and the mixture was vigorously stirred at room temperature. The conversion was checked by TLC and pushed up with manganese oxide supplementation (8.32 eq.). After 48 h, the black suspension was filtered on a Celite ${ }^{\circledR}$ pad and on silica gel before concentration in vacuo.

${ }^{1} \mathrm{H}$ NMR $\left(400 \mathrm{MHz}, \mathrm{CDCl}_{3}\right) \delta(\mathrm{ppm}) 7.61-7.56\left(\mathrm{~m}, 2 \mathrm{H}, \mathrm{H}_{\mathrm{Ar}}\right), 7.19(\mathrm{dd}, J=17.0,10.5 \mathrm{~Hz}$, $\left.1 \mathrm{H}, \mathrm{H}_{1}\right), 6.90\left(\mathrm{~d}, J=8.4 \mathrm{~Hz}, 1 \mathrm{H}, \mathrm{H}_{\mathrm{Ar}}\right), 6.43\left(\mathrm{dd}, J=17.0,1.8 \mathrm{~Hz}, 1 \mathrm{H}, \mathrm{H}_{3}\right), 5.87(\mathrm{dd}, J=10.5$, $\left.1.8 \mathrm{~Hz}, 1 \mathrm{H}, \mathrm{H}_{3}\right), 3.96$ and $3.95\left(\mathrm{~s}, 3 \mathrm{H}, \mathrm{OCH}_{3}\right)$.

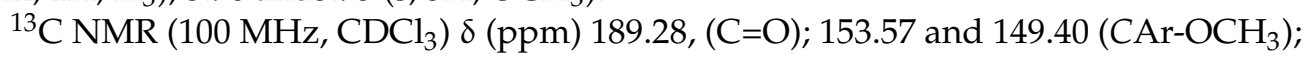
132.07, (CH=); 130.56, (CAr); 129.39, $\left(=\mathrm{CH}_{2}\right) ; 123.56$, (CHAr); 110.92, (CHAr); 110.11, (CHAr); 56.23, $\left(\mathrm{OCH}_{3}\right) ; 56.15,\left(\mathrm{OCH}_{3}\right)$.

MS m/z (\%): $192\left(\mathrm{M}^{+\bullet}, 50\right), 165$ (100), 122 (20), 107 (22), 91 (20), 79 (78), 77 (40), 63 (25), 55 (60) and 51 (39).

1-(3,4-Dimethoxyphenyl)-2,3-epoxypropan-1-ol 5: Isolated as a mixture of diastereomers from the reaction of $\mathbf{1}$.

${ }^{1} \mathrm{H}$ NMR $\left(400 \mathrm{MHz} \mathrm{CDCl}_{3}\right): 3: 7$ mixture of 2 diastereomers. $\delta(\mathrm{ppm}) 6.99-6.85(\mathrm{~m}, 3 \mathrm{H}$, $\left.\mathrm{H}_{\mathrm{Ar}}\right), 4.87$ and $4.44\left(\mathrm{~d}, 1 \mathrm{H}, \mathrm{H}_{1}\right), 3.91$ and $3.81\left(\mathrm{~s}, 3 \mathrm{H}, \mathrm{OCH}_{3}\right), 3.23\left(\mathrm{~m}, 1 \mathrm{H}, \mathrm{H}_{2}\right), 2.77-2.97(\mathrm{~m}$, $\left.2 \mathrm{H}, \mathrm{H}_{3}\right)$.

${ }^{13} \mathrm{C} \mathrm{NMR}\left(100 \mathrm{MHz}, \mathrm{CDCl}_{3}\right)$ : 3:7 mixture of 2 diastereomers. $\delta(\mathrm{ppm}) 149.36$ and $149.12\left(\mathrm{CAr}^{\left.-\mathrm{OCH}_{3}\right)} ; 149.31\right.$ and $149.16\left(\mathrm{C}^{\prime} \mathrm{Ar}-\mathrm{OCH}_{3}\right) ; 132.99,(\mathrm{CAr}) ; 132.09,\left(\mathrm{C}^{\prime} \mathrm{Ar}\right) ; 118.92$, (C'HAr); 118.81, (CHAr); 111.25, (CHAr); 109.68, (C'HAr); 109.58, (CHAr); 109.55, (C'HAr); 74.27, (C-OH); 70.84, (C'-OH); 56.09-56.05 and 56.02, $\left(\mathrm{CH}, \mathrm{OCH}_{3}, \mathrm{OCH}_{3}\right) ; 56.09-56.05$ and 55.17, $\left(\mathrm{C}^{\prime} \mathrm{H}, \mathrm{OC}^{\prime} \mathrm{H}_{3}, \mathrm{OC}^{\prime} \mathrm{H}_{3}\right) ; 45.50,\left(\mathrm{CH}_{2}\right) ; 43.79,\left(\mathrm{C}^{\prime} \mathrm{H}_{2}\right)$.

MS $m / z$ (\%): diastereomer 1 (maj.) $210\left(\mathrm{M}^{+\bullet}, 35\right), 167$ (100), 165 (14), 151 (54), 139 (67), 124 (23), 108 (19), 107 (15), 77 (25) and 65 (15).

1-(3,4-Dimethoxyphenyl)prop-2-en-1-ol 6: 2 (8.86 $\mathrm{mmol})$ under a nitrogen atmosphere was dissolved in distilled THF $(0.11 \mathrm{M})$ and put in a $-80{ }^{\circ} \mathrm{C}$ bath. Vinyl magnesium bromide $\left(\mathrm{C}_{2} \mathrm{H}_{3} \mathrm{MgBr}, 1.19\right.$ eq.) in THF was added slowly. The reaction was stirred and let warm to room temperature until TLC analysis indicated that no starting material remained $(7 \mathrm{~h})$. The reaction was quenched with a saturated aqueous $\mathrm{NaCl}$ solution and extracted with EtOAc. The combined organic layers were washed with an aqueous solution of saturated $\mathrm{NaCl}$, dried on $\mathrm{MgSO}_{4}$, filtrated and concentrated in vacuo (81\%).

${ }^{1} \mathrm{H}$ NMR (400 MHz, $\left.\mathrm{CDCl}_{3}\right) \delta(\mathrm{ppm}) 6.89-6.85\left(\mathrm{~m}, 2 \mathrm{H}, \mathrm{H}_{\mathrm{Ar}}\right) ; 6.81\left(\mathrm{~m}, 1 \mathrm{H}, \mathrm{H}_{\mathrm{Ar}}\right), 6.02$ $\left(\mathrm{ddd}, J=17.2,10.3,5.9 \mathrm{~Hz}, 1 \mathrm{H}, \mathrm{H}_{2}\right), 5.33-5.15\left(\mathrm{~m}, 2 \mathrm{H}, \mathrm{H}_{3}\right), 5.11(\mathrm{dd}, J=5.9,1.5 \mathrm{~Hz}, 1 \mathrm{H}$, $\left.\mathrm{H}_{1}\right), 3.85$ and $3.84\left(\mathrm{~s}, 3 \mathrm{H}, \mathrm{OCH}_{3}\right) .{ }^{13} \mathrm{C} \mathrm{NMR}\left(100 \mathrm{MHz}, \mathrm{CDCl}_{3}\right) \delta(\mathrm{ppm}) 149.21$ and 148.71 $\left(\mathrm{CAr}_{-} \mathrm{OCH}_{3}\right)$; 140.37, $(\mathrm{CH}=) ; 135.41,(\mathrm{CAr}) ; 118.76,(\mathrm{CHAr}) ; 115.01,\left(=\mathrm{CH}_{2}\right) ; 111.13,(\mathrm{CHAr})$; 109.59, (CHAr); 75.18, (CH-OH); 56.04, $\left(\mathrm{OCH}_{3}\right)$; 55.95, $\left(\mathrm{OCH}_{3}\right)$.

MS m/z (\%): $194\left(\mathrm{M}^{+\bullet}, 97\right), 165$ (29), 163 (62), 151 (33), 139 (100), 138 (27), 91 (34), 79 (31), 77 (36) and 55 (51). 
3-(3,4-Dimethoxyphenyl)prop-2-en-1-ol 8: 3 (1 mmol) was dissolved in EtOH (0.35 M) and placed under a nitrogen atmosphere. $\mathrm{NaBH}_{4}(1.25$ eq.) was added. The mixture was then stirred for $1.2 \mathrm{~h}$ at room temperature. The work-up consisted of EtOH evaporation under vacuo, solubilization in distilled water and extraction with EtOAc. Organic layers were pooled, dried over $\mathrm{MgSO}_{4}$ filtrated and concentrated in vacuo $(100 \%)$.

${ }^{1} \mathrm{H}$ NMR $\left(400 \mathrm{MHz}, \mathrm{CDCl}_{3}\right): \delta(\mathrm{ppm}) 6.98-6.88\left(\mathrm{~m}, 2 \mathrm{H}, \mathrm{H}_{\mathrm{Ar}}\right), 6.82(\mathrm{~d}, J=8.2 \mathrm{~Hz}, 1 \mathrm{H}$, $\left.\mathrm{H}_{\mathrm{Ar}}\right), 6.55\left(\mathrm{~d}, J=15.9 \mathrm{~Hz}, 1 \mathrm{H}, \mathrm{H}_{3}\right), 6.25\left(\mathrm{dt}, J=15.9,5.8 \mathrm{~Hz}, 1 \mathrm{H}, \mathrm{H}_{2}\right), 4.31(\mathrm{~d}, J=5.8 \mathrm{~Hz}, 2 \mathrm{H}$, $\left.\mathrm{H}_{1}\right), 3.90$ and $3.88\left(\mathrm{~s}, 3 \mathrm{H}, \mathrm{OCH}_{3}\right)$.

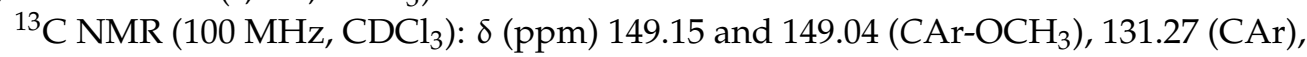
129.86 $(\mathrm{CH}=), 126.67(=\mathrm{CH}), 119.81(\mathrm{CHAr}), 111.24(\mathrm{CHAr}), 108.97(\mathrm{CHAr}), 63.95\left(\mathrm{CH}_{2}\right)$, $56.04\left(\mathrm{OCH}_{3}\right)$ and $55.94\left(\mathrm{OCH}_{3}\right)$.

MS m/z (\%): $194\left(\mathrm{M}^{+\bullet}, 68\right), 165$ (14), 151 (100), 138 (53), 119 (16), 107 (13), 91 (33), 79 (14), 77 (26) and 55 (13).

\section{Results and Discussion}

\subsection{Enzymatic Reaction of Methyleugenol}

To study the reaction, $\mathbf{1}$ was taken as the model substrate for preliminary investigations. Parameters of 1 oxidation by laccase were screened with a focus on enzyme weight ratio, mediator nature and ratio, co-solvent, $\mathrm{pH}$ and temperature.

\subsubsection{Controls}

A couple of negative controls were performed. For the first control, $1(1.03 \mathrm{mmol}$, $185.0 \mathrm{mg}$ ) and laccase (10\% LA, $19.10 \mathrm{mg}$ ) were incubated in aqueous acetate buffer $\mathrm{pH} 5$ under an oxygen atmosphere for $24 \mathrm{~h}$ at $40{ }^{\circ} \mathrm{C}$, before extraction with EtOAc. ME 1 was quantitively recovered unchanged, with no conversion being noticed by GC/MS analysis. For the second control performed with two mediators, $\mathbf{1}(1.03 \mathrm{mmol}, 184.2 \mathrm{mg}$ and $1.02 \mathrm{mmol}, 182.2 \mathrm{mg}$ ) and mediator (20\% HOBt, $0.20 \mathrm{mmol}, 27.3 \mathrm{mg}$ and $20 \%$ TEMPO, $0.23 \mathrm{mmol}, 35.5 \mathrm{mg}$ ) were incubated in aqueous acetate buffer $\mathrm{pH} 5$ under an oxygen atmosphere for $24 \mathrm{~h}$ at $40^{\circ} \mathrm{C}$ before extraction with EtOAc. ME 1 was quantitively recovered unchanged, with no conversion being noticed by GC/MS neither. It can be concluded from these controls that laccase is not able to oxidize $\mathbf{1}$ on its own and that the mediator alone cannot oxidize 1 either. Both mediator and laccase are involved in the oxidation mechanism.

\subsubsection{Effect of $\mathrm{pH}$ and Temperature}

Laccases are known to have optimal $\mathrm{pH}$ ranges between 3.5 and 5 with hydrogen donor substrates [15]. To specifically evaluate the effect of $\mathrm{pH}$ on our reactions of interest, five different $\mathrm{pH}$ were tested (4-9), along with an additional test in deionized water (DIW). The effect was quickly assessed by monitoring the remaining 1 in the crude reaction mixture after extraction and GC/MS analysis (Figure 2).

Our experiments show the stability of laccase-mediator oxidation of 1 in the $4-9 \mathrm{pH}$ range and in DIW (not shown).

Laccases optimal temperatures are known to be in the range from 50 to $70{ }^{\circ} \mathrm{C}$, but they can also exhibit activity at a lower temperature, such as physiological temperature [15]. To specifically evaluate the effect of temperature on our model reaction, four different temperatures were tested. Once again, the effect was quickly assessed by monitoring the remaining 1 in the crude reaction mixture after extraction and GC/MS analysis (Figure 3). 


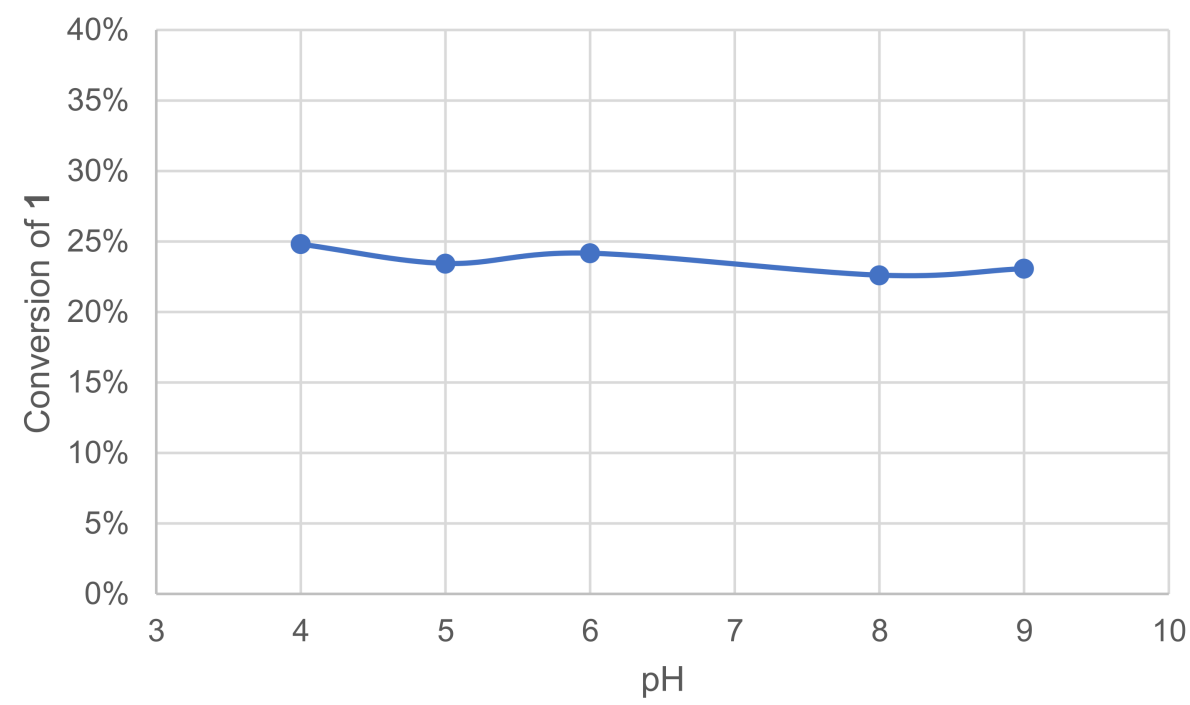

Figure 2. Effect of $\mathrm{pH}$ on the conversion of 1 in the laccase-catalyzed oxidation (LA $10 \%$ w/w, $\mathrm{HOBt}$ $20 \mathrm{~mol} \%$, buffer $0.25 \mathrm{M}, \mathrm{O}_{2}$ atmosphere, incubation for $24 \mathrm{~h}, 40^{\circ} \mathrm{C}, 200 \mathrm{rpm}$ ).

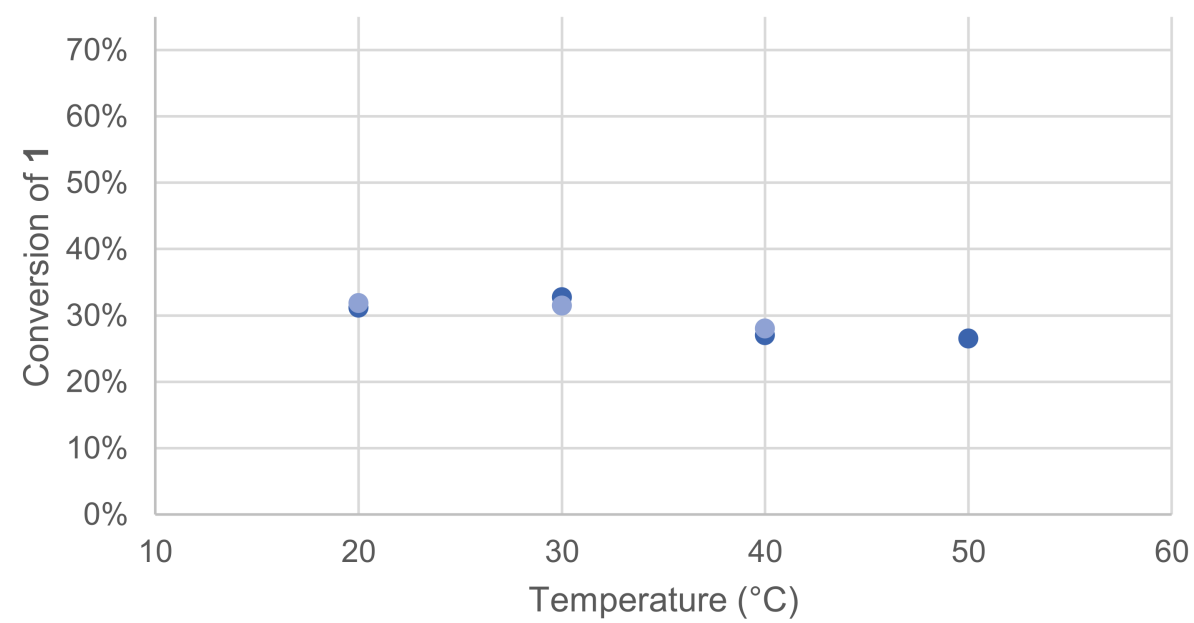

Figure 3. Effect of temperature on the conversion of $\mathbf{1}$ in the laccase-catalyzed oxidation (LA $10 \%_{w / w}$, HOBt $20 \mathrm{~mol} \%$, acetate buffer pH5 $0.25 \mathrm{M}, \mathrm{O}_{2}$ atmosphere, incubation for $24 \mathrm{~h}, 200 \mathrm{rpm}$ ). Reactions run in duplicate.

The optimal temperature was found to be between 20 and $30{ }^{\circ} \mathrm{C}$ for the reaction of $\mathbf{1}$.

\subsubsection{Effect of Co-Solvent}

A co-solvent can be added to the medium to improve substrate solubility in water. The positive effect of co-solvent such as EtOAc on 2,6-dimethoxyphenol dimerization by Trametes pubescens laccase was already reported [42]. Various co-solvents, miscible or not with water, were tested, and the activity was measured by GC/MS analysis (Figure 4).

Toluene and EtOAc, which are immiscible with water at this temperature, gave the worst conversion rates. DMF and dioxane allowed for higher conversion rates.

\subsubsection{Effect of Oxygenation of the Medium}

Medium oxygenation can be a limiting factor of an aerobic oxidation reaction as the oxygen dissolution rate in water is low. An oxygen solubility of $39.04 \mathrm{mg} / \mathrm{L}$ in distilled water at $20^{\circ} \mathrm{C}$ has been determined for a saturated $\mathrm{O}_{2}$ atmosphere [43]. 


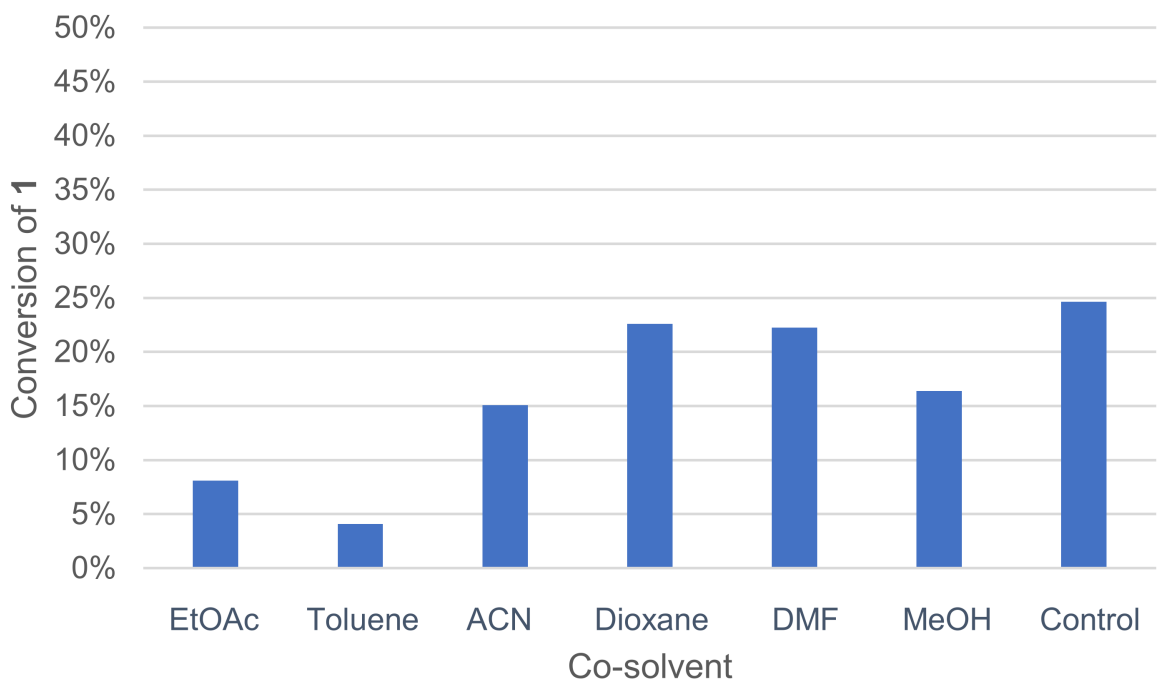

Figure 4. Effect of co-solvents on the conversion of 1 in the laccase-catalyzed oxidation (LA $10 \%$ w HOBt $20 \mathrm{~mol} \%$, acetate buffer pH5 $0.25 \mathrm{M}$, co-solvent $50 \%$ v/v buffer, $\mathrm{O}_{2}$ atmosphere, incubation for $\left.24 \mathrm{~h}, 40{ }^{\circ} \mathrm{C}, 200 \mathrm{rpm}\right)$.

Various oxygenation methods were tested: closed vessel, open vessel at ambient atmosphere, vessel under an oxygen atmosphere and oxygenation by controlled in situ catalase degradation of hydrogen peroxide (Figure 5). Once again, the effect was quickly assessed by monitoring the remaining $\mathbf{1}$ in the crude reaction mixture after extraction and GC/MS analysis.

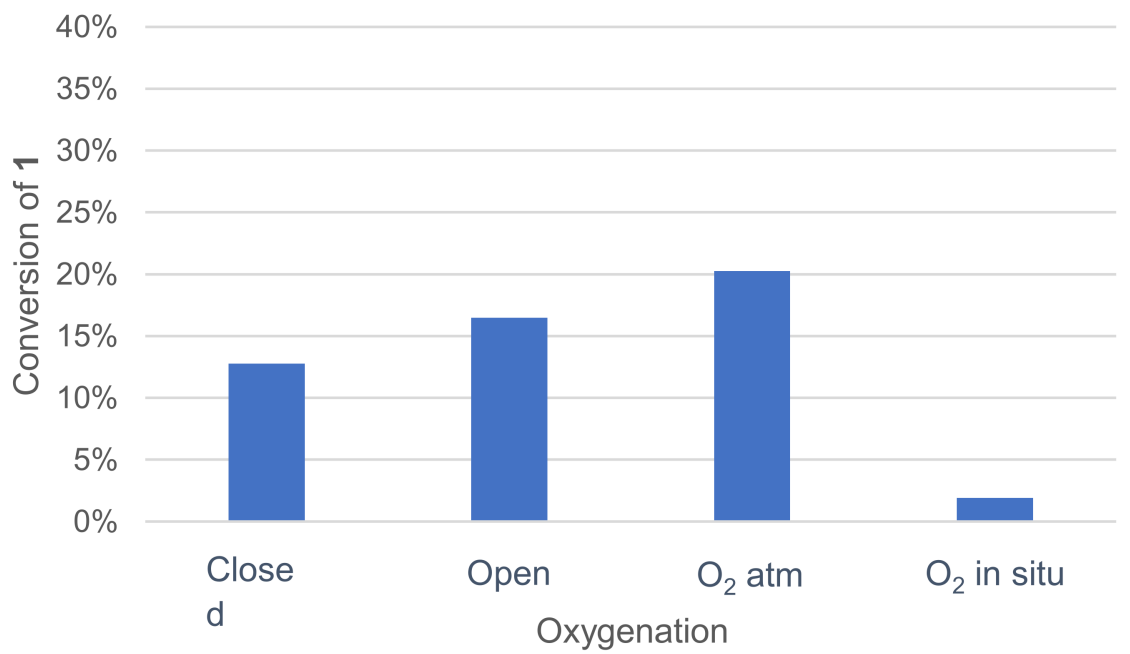

Figure 5. Effect of oxygenation on the conversion of $\mathbf{1}$ in the laccase-catalyzed oxidation (LA $5 \%$, HOBt $10 \mathrm{~mol} \%$, acetate buffer pH5 0.5M, DMF $5 \%$, incubation for $24 \mathrm{~h}, 30{ }^{\circ} \mathrm{C}, 200 \mathrm{rpm}$ ).

Oxygenation with the catalase- $\mathrm{H}_{2} \mathrm{O}_{2}$ system did not improve 1 conversion. A noticeable enhancement of the conversion was observed when the reaction was run under an oxygen atmosphere.

\subsubsection{Effect of Reaction Time}

Increasing the reaction time usually allows a reactive system to reach the total conversion if there is no limitation by reagents quantities. The acylation of palmarosa essential oil by a lipase from Candida rugosa was reported to reach a $46 \%$ conversion after $24 \mathrm{~h}$, whereas total conversion was obtained after $96 \mathrm{~h}$. [44] The effect of reaction time was measured by a kinetic plot, and the conversion of $\mathbf{1}$ was assessed by monitoring the remaining $\mathbf{1}$ in the crude reaction mixture after extraction and GC/MS analysis. 
The assays showed that the conversion raised significantly over a 5h-period with an initial reaction rate of ca. $32 \mathrm{mM} \cdot \mathrm{h}^{-1}$. Conversion plateau was reached at $25-30 \%$ after $10 \mathrm{~h}$, and this might be due to enzyme and/or mediator deactivation. The preincubation of some components was thus investigated mostly to evaluate a possible inhibiting effect of substrate $\mathbf{1}$ on the enzymatic system. The enzyme and $\mathbf{1}$ were thus engaged in our conditions in the absence of a mediator, while in parallel, the mediator and 1 were engaged similarly in the absence of the enzyme. After $24 \mathrm{~h}$, the laccase-mediator system was completed by the addition of the missing component and the reaction was run for another $24 \mathrm{~h}$. No significant differences were observed between these two experiments and the one in Figure 6.

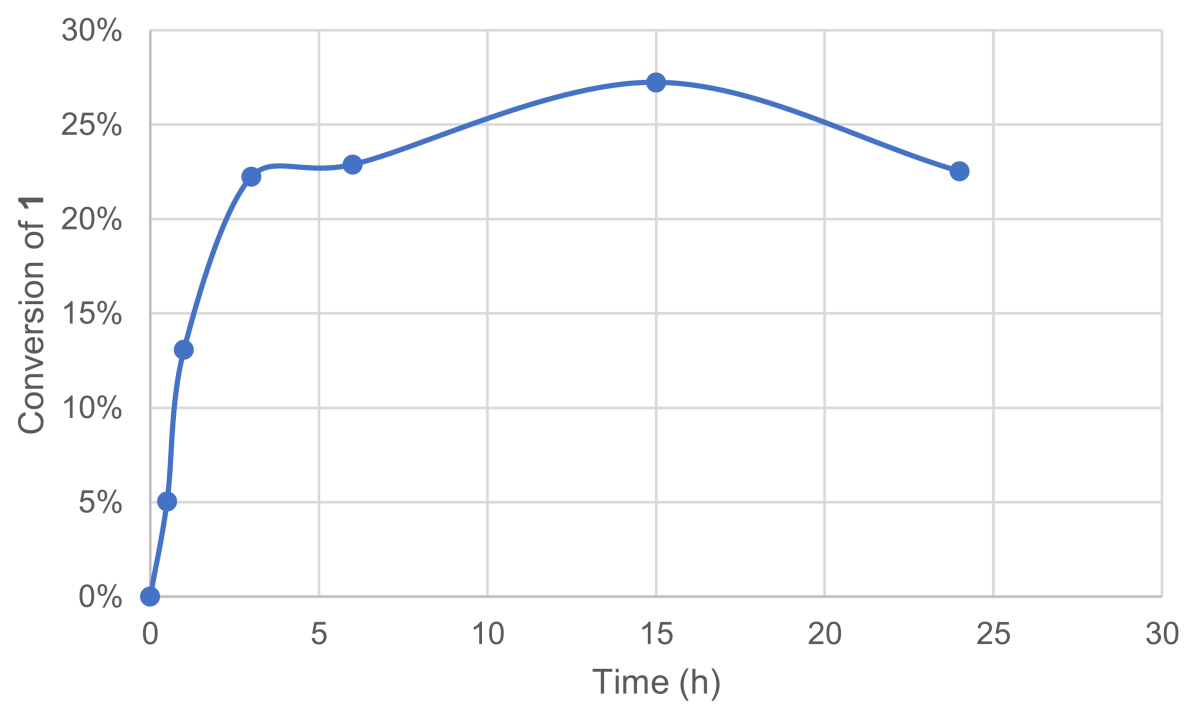

Figure 6. Effect of time reaction on the conversion of 1 in the laccase-catalyzed oxidation (LA $10 \%_{w / w}$, HOBt $20 \mathrm{~mol} \%$, acetate buffer pH5 $0.25 \mathrm{M}, \mathrm{O}_{2}$ atmosphere, incubation $40^{\circ} \mathrm{C}, 200 \mathrm{rpm}$ ).

\subsubsection{Effect of Enzyme Source and Concentration}

Three laccases were used in this study to compare their activity. Laccase LTv was purchased from Sigma Aldrich (laccase from Trametes versicolor), laccase LA is a non-GMO enzyme purchased from Amano enzyme (laccase M120) and laccase LEH was obtained from ISM2 laboratory (Aix-Marseille Université) and produced by heterologous expression. These variable sources exhibited different specific activities that are not always precisely determined by vendors, which makes it difficult to design experiments for a comparison purpose. An SDS-PAGE test was performed on LA and LTv, showing that enzymes purity was rather low (see Supplementary Materials). In these reactivity tests, laccases were used in varying weight $\%$ relative to $\mathrm{ME}$, and a comparison was made by measuring oxidation products in the crude reaction mixture after extraction and GC/MS analysis. The effect of substrate concentration was assayed on another side and was found negligible (see Supplementary Materials).

Increasing enzyme quantity could help reach a better conversion into oxidation products, but the increase was somehow limited beyond 0.25. Laccase LEH, shown to be of the highest purity, was clearly superior for this reaction with oxidation products formed with more than $50 \%$ yield with only $5 \mathrm{wt} \%$. Mediator quantity is also an important parameter in relation to enzyme quantity. Compared to the conditions of Figure 7, when the reaction was performed with 4 -fold HOBt as the mediator, conversion of $\mathbf{1}$ increased by ca. 2 -fold (not shown). 


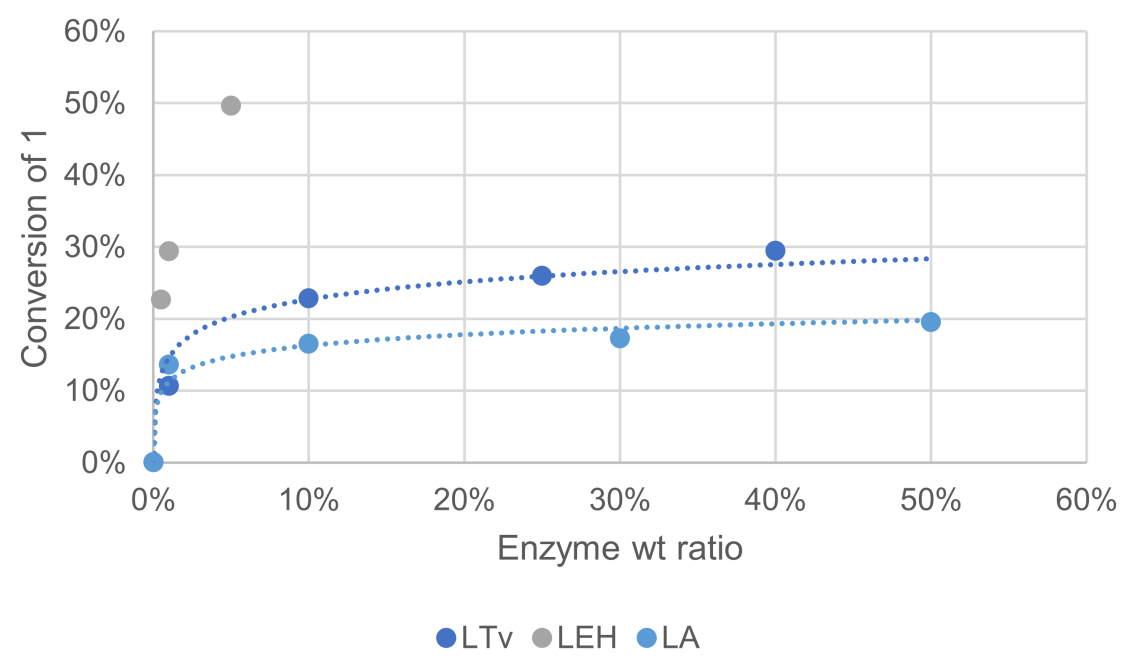

Figure 7. Effect of the enzyme source on the conversion of $\mathbf{1}$ in the laccase-catalyzed oxidation (laccase $1-50 \% \%_{w / w}, \mathrm{HOBt} 10 \mathrm{~mol} \%$, acetate buffer $\mathrm{pH} 50.25 \mathrm{M}, \mathrm{O}_{2}$ atmosphere, incubation for $24 \mathrm{~h}$, $\left.40{ }^{\circ} \mathrm{C}, 200 \mathrm{rpm}\right)$.

\subsubsection{Effect of the Mediator Type}

Various types of mediators are already described in the literature and typically used in combination with laccases, such as 1-hydroxybenzotriazole (HOBt), TEMPO and ABTS [18]. Their role is to link the enzyme with substrates that are not compatible for steric or electronic reasons. A mediator is a molecule of low molecular weight, which is oxidizable by laccase to a high potential intermediate, and whose reduced and oxidized forms must be stable [14]. The mediator must not deteriorate during oxidation cycles nor deactivate the enzyme. After being oxidized by laccase, the mediator oxidizes the substrate in a non-enzymatic process. The mediator returns to its initial reduced form and is ready to perform a new cycle. These mediators have redox potential compatible with the enzyme as well as a broader substrate scope. All of those mediators are of synthetic origin. Natural mediators can also be used, such as violuric acid (VA) and vanillin [28]. A pool of natural and non-natural mediators was thus tested (Figure 8).

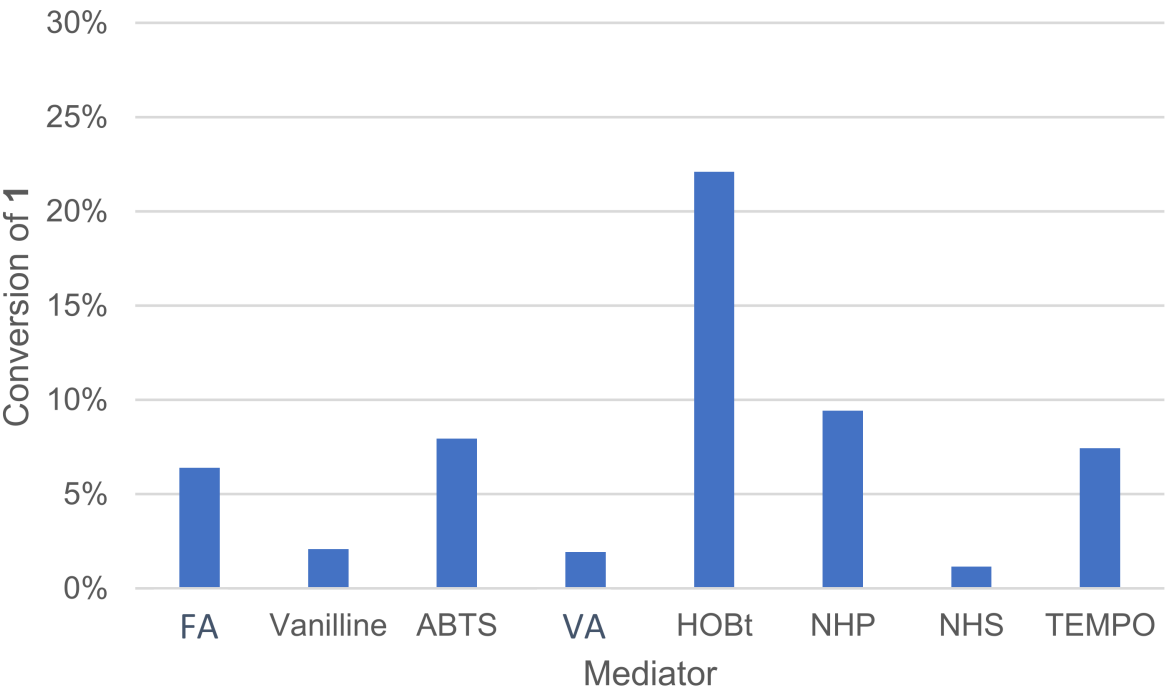

Figure 8. Effect of the mediator type on the conversion of $\mathbf{1}$ in the laccase-catalyzed oxidation (LA $10 \%$ w/w, mediator $20 \mathrm{~mol} \%$, acetate buffer pH5 $0.25 \mathrm{M}, \mathrm{O}_{2}$ atmosphere, incubation for $24 \mathrm{~h}$, $\left.40{ }^{\circ} \mathrm{C}, 200 \mathrm{rpm}\right)$. NPH: N-hydroxyphthalimide, NHS: N-hydroxysuccinimide, VA: violuric acid, FA: ferulic acid. 
The mediator type had an important effect on conversion, and no or very little reaction occurred in our conditions when using N-hydroxysuccinimide (NHS), vanillin, violuric acid (VA) and ferulic acid (FA). The profile of oxidation products distribution was also affected by mediator choice. In the same proportion, HOBt converted more 1 than TEMPO, but HOBt produced more oxidative cleavage products, such as veratraldehyde 2 and 3(3,4-dimethoxyphenyl)prop-2-en-1-one 3 than TEMPO (Figure 9). TEMPO was also able to convert 1 into 1-(3,4-dimethoxyphenyl)prop-2-en-1-one 4.

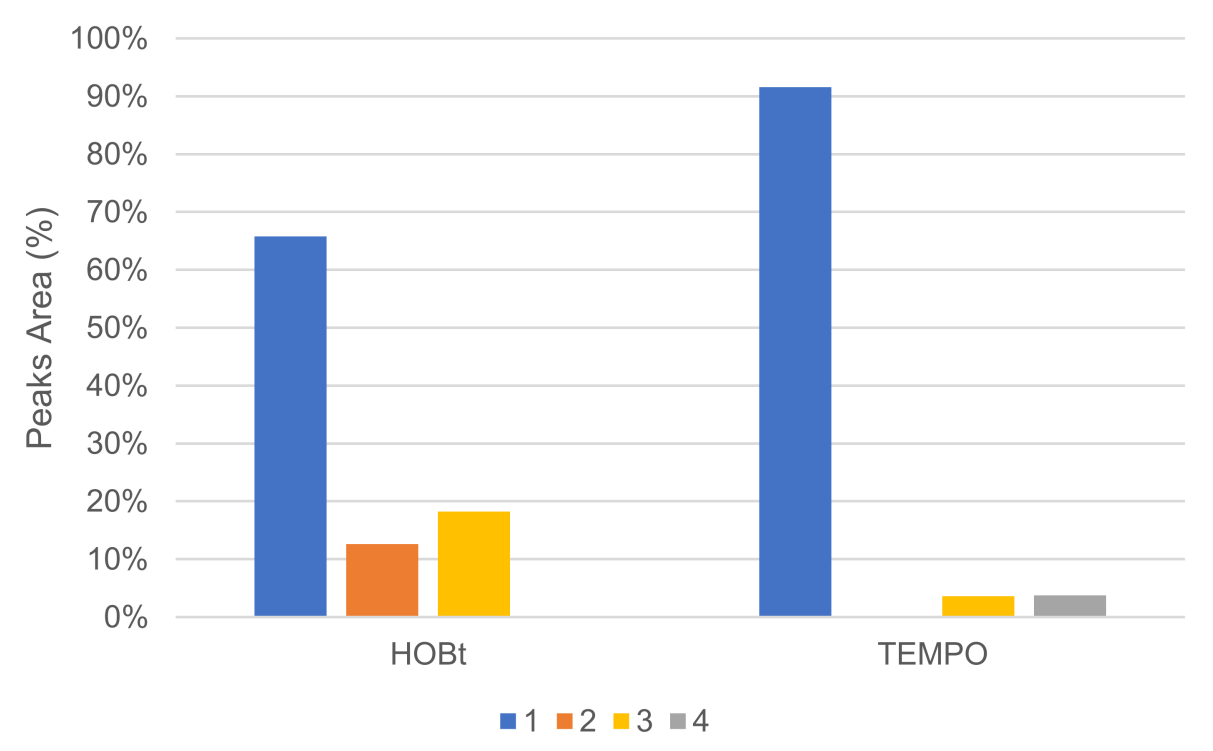

Figure 9. Comparison of oxidation products using HOBt or TEMPO as \%area in the crude product determined by GC/MS (LA $10 \%{ }_{w / w}$, mediator $50 \mathrm{~mol} \%$, acetate buffer $\mathrm{pH} 50.25 \mathrm{M}, \mathrm{O}_{2}$ atmosphere, incubation for $\left.24 \mathrm{~h}, 40^{\circ} \mathrm{C}, 200 \mathrm{rpm}\right)$.

As organic molecules, mediators are extracted during work-up together with unconverted 1 and oxidation products. Using immobilized (supported) mediators could be an option as they can be easily separated from the reaction mixture by filtration. Supported HOBt and TEMPO were tested on $\mathbf{1}$ on our standard conditions but did not show any activity (not shown). In parallel, a positive control experiment was set using 4-methoxybenzyl alcohol oxidation [18]. Without a mediator, no conversion was observed. Free HOBt allowed for substrate oxidation as expected with $34 \%$ and the formation of resp. $18 \%$ and $12 \%$ oxidation products such as 3 and 4 . When using supported mediators, such as silica-bound TEMPO, PS-bound TEMPO and PS-bound HOBt, no reaction occurred, and the substrate was quantitatively recovered after work-up. Thus, we hypothesized that these supported mediators could not be activated by laccase within the binding pocket, eventually enabling substrate oxidation.

\subsubsection{Effect of Mediator Concentration}

The mediator in the laccase-mediator system is an intermediate that should switch between its oxidized and reduced form in a catalytic cycle. Following this scheme, each molecule of the mediator should be reusable endlessly. The effect of mediator concentration on the conversion of $\mathbf{1}$ was investigated (Figure 10). The conversion was monitored by GC/MS measurement of $\mathbf{1}$ after extraction of the crude reaction mixture. With HOBt, conversion increased with the ratio reaching a plateau at ca. $50 \mathrm{~mol} \%$. With TEMPO, however, conversion remained low regardless of its ratio. 


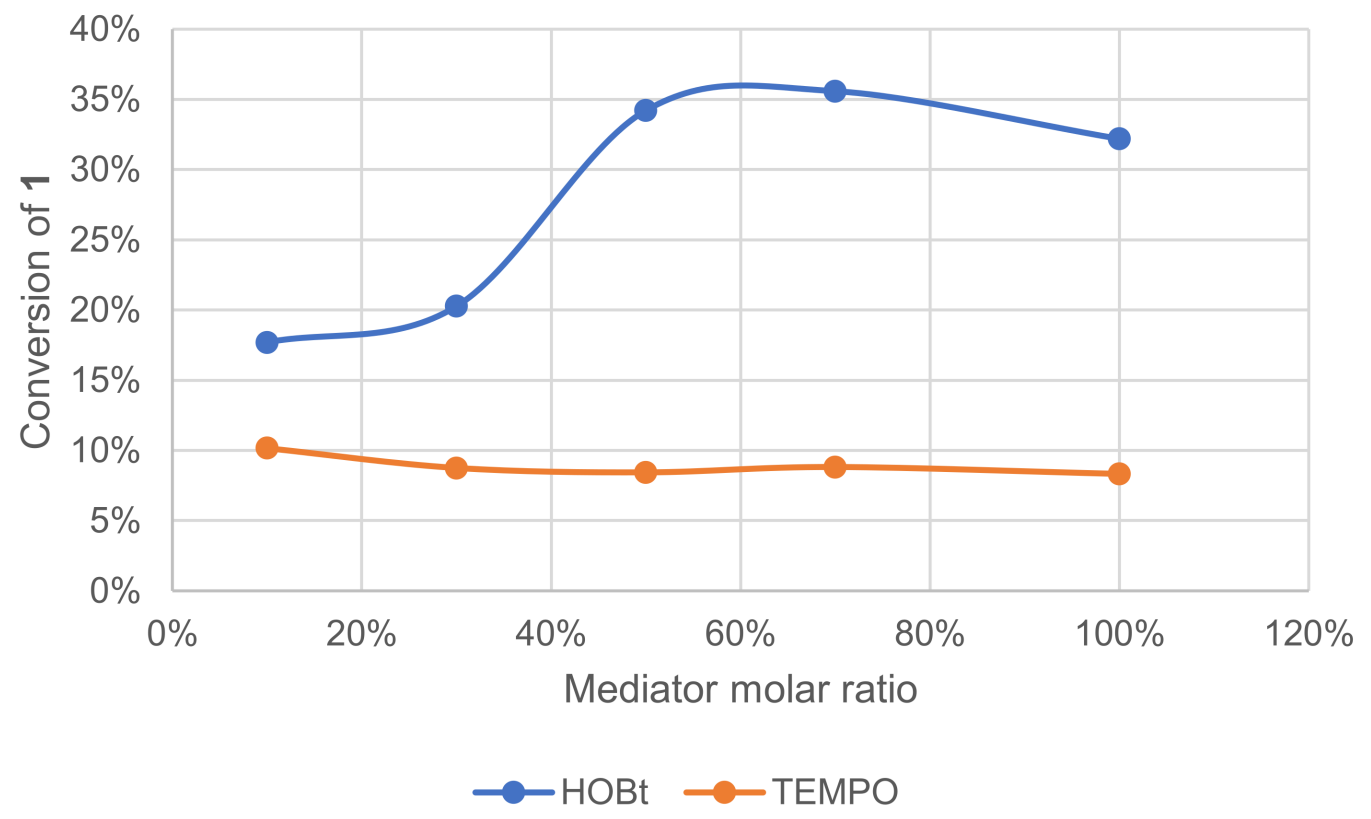

Figure 10. Effect of the mediator type and ratio on the conversion of $\mathbf{1}$ in the laccase-catalyzed oxidation (LA $10 \%_{w / w}$, mediator, acetate buffer pH5 $0.25 \mathrm{M}, \mathrm{O}_{2}$ atmosphere, incubation for $24 \mathrm{~h}$, $\left.40{ }^{\circ} \mathrm{C}, 200 \mathrm{rpm}\right)$.

3.1.9. Hypothesis of a Fast Deactivation and Sequential Supply of Fresh Enzyme and Mediator

Previous results obtained during this study suggested a fast deactivation of the laccasemediator system in our conditions. This hypothesis was further tested with reactions conducted with a sequential supply of fresh enzymes and the mediator under time-course monitoring. A total of 4 additions of $5 \mathrm{wt} \%$ of laccase LA was necessary to reach $100 \%$ conversion and 93\% yield of 2 and 3, favorable to the former at 54\% (Figure 11). Conversely, a total of 3 additions of $10 \mathrm{~mol} \%$ HOBt allowed a $100 \%$ conversion and $87 \%$ yield, with a $60 \%$ selectivity in favor of 3 .

These results confirm the deactivation of both the enzyme LA, already described for a laccase from Trametes villosa with HOBt [24], but also the deactivation of HOBt, presumably by degradation.

\subsection{Mechanistic Investigations}

Identification of oxidation products of $\mathbf{1}$ was possible upon daily addition of enzyme and mediator until full conversion of $\mathbf{1}$ was attained (Figure 12). Isolation by chromatography on silica gel and confirmation by chemical synthesis allowed to identify compounds $\mathbf{2}$, 3 and 4. 

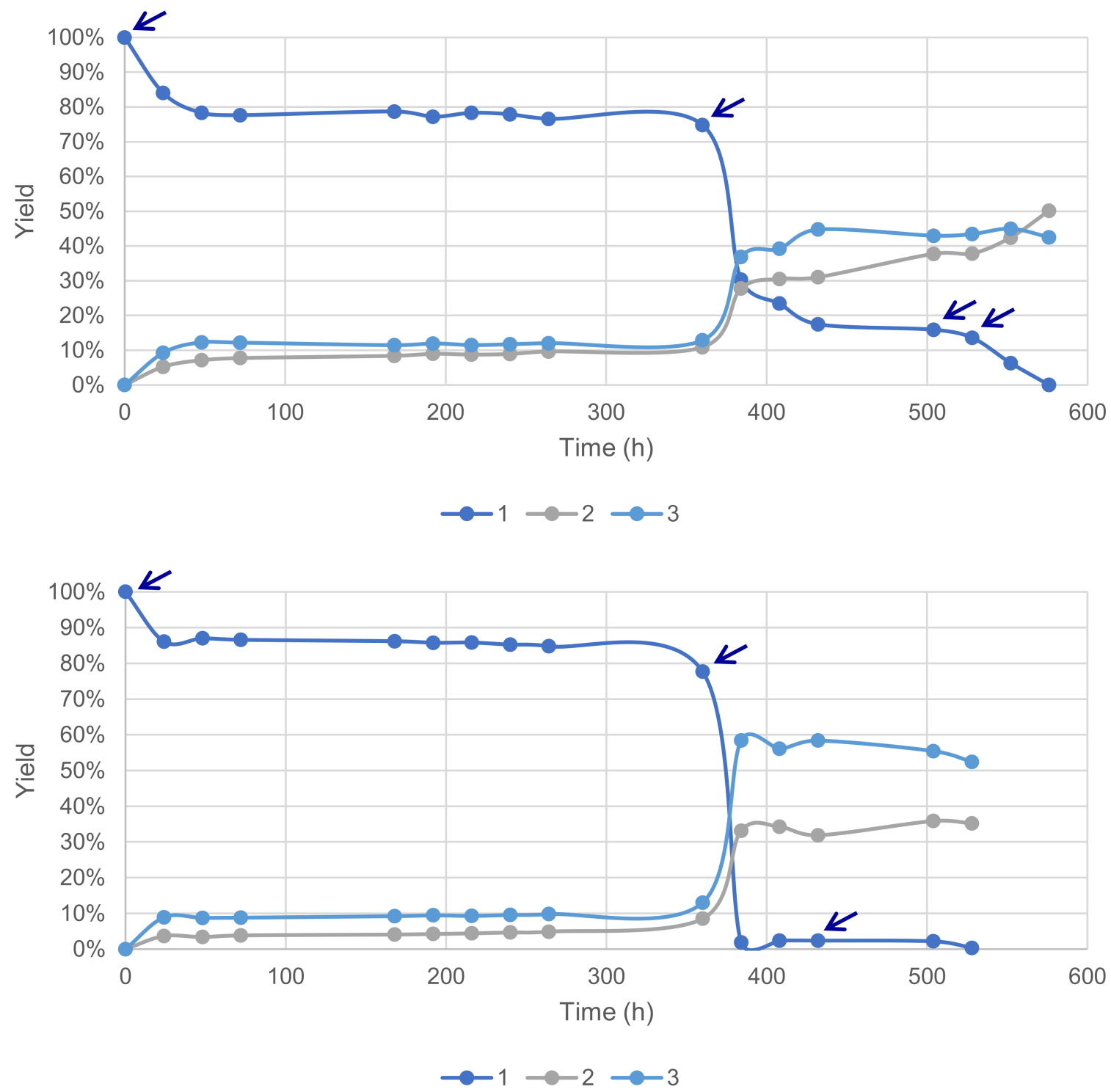

Figure 11. Sequential supply of fresh enzymes (top) and the mediator (bottom) marked with arrows for each addition of material (acetate buffer pH5, $6 \mathrm{mmol}$ substrate $10.12 \mathrm{M}, \mathrm{O}_{2}$ atmosphere, $40{ }^{\circ} \mathrm{C}$, magnetic stirring).

The reaction mechanism was hypothesized based on intermediates identified and their observed rate of formation/conversion (Figure 13). ME 1 could either oxidize on its allylic position to 5 or first isomerize into 9 and then further oxidize to $\mathbf{6}$. A concerted isomerization/oxidation could also convert 1 into 6 . The oxidation of activated alcohol functions of $\mathbf{5}$ and $\mathbf{6}$ to their corresponding carbonyl compounds could thus take place leading to 4 and 3 , respectively. Veratraldehyde 2 could be either formed upon oxidative cleavage of all these intermediates and could eventually deliver benzoic acid derivative upon an additional oxidation step. 


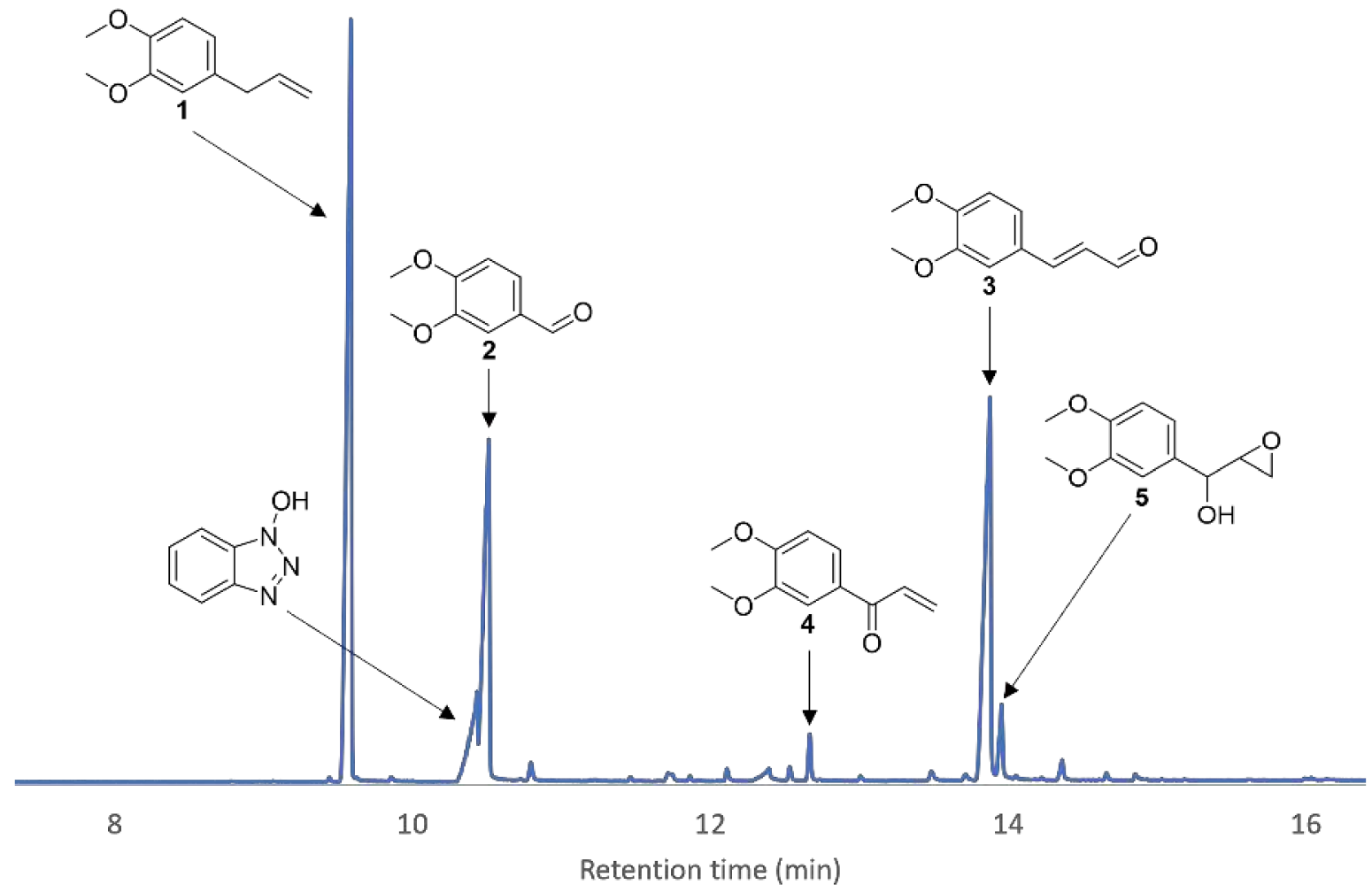

Figure 12. Zoom-in of a GC/MS chromatogram of the crude product after the enzymatic reaction of $\mathbf{1}$ with HOBt as a mediator. Five peaks were identified as oxidation products besides HOBt.

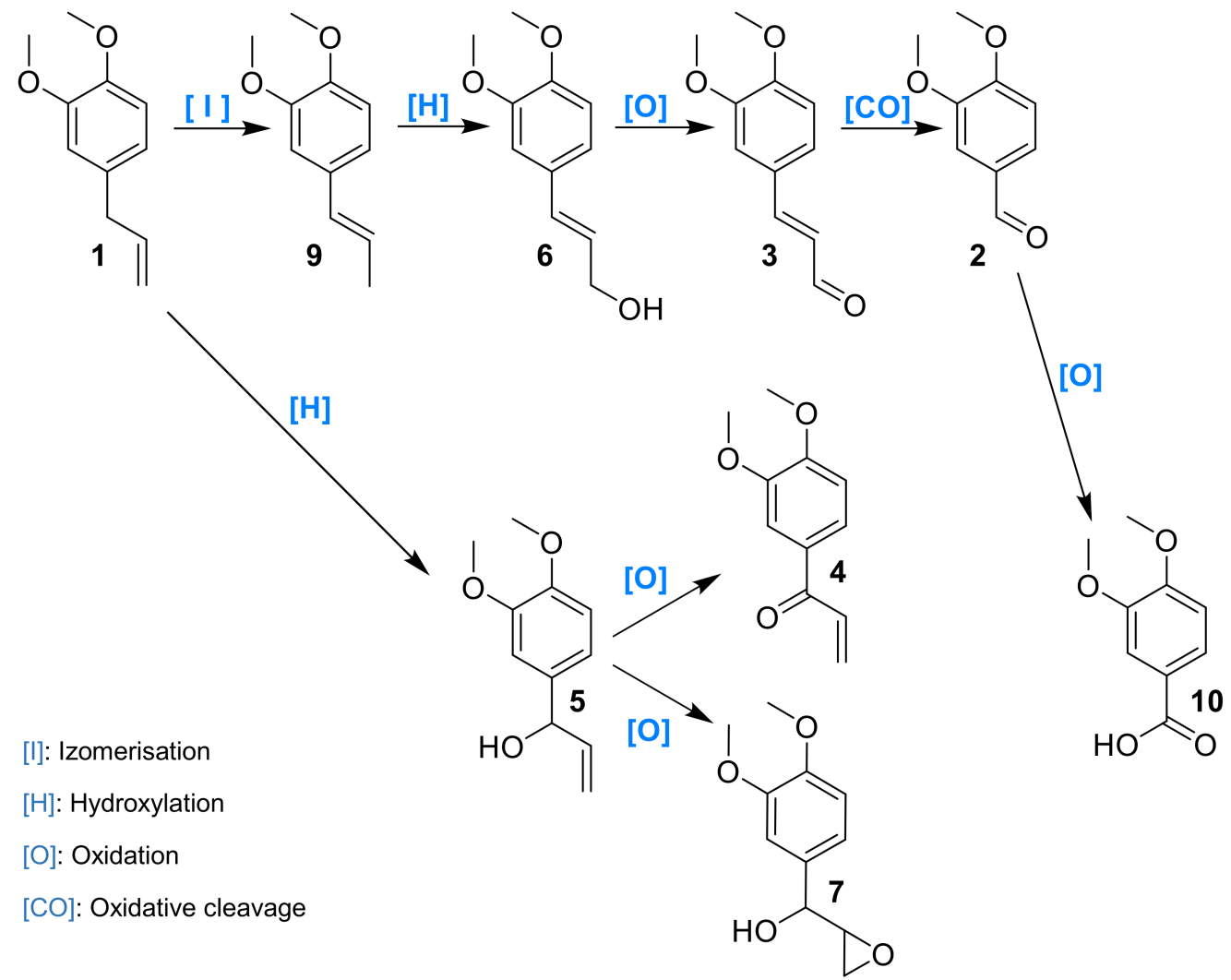

Figure 13. Hypothetical mechanism of the oxidation of $\mathbf{1}$ by the laccase-mediator system. 
Each step of this hypothetic mechanism was checked by the submission of the corresponding intermediate, either isolated, purchased or synthesized, to the enzymatic reaction, with HOBt as a mediator. Products and their proportion for each reaction are summarized in Figure 14.

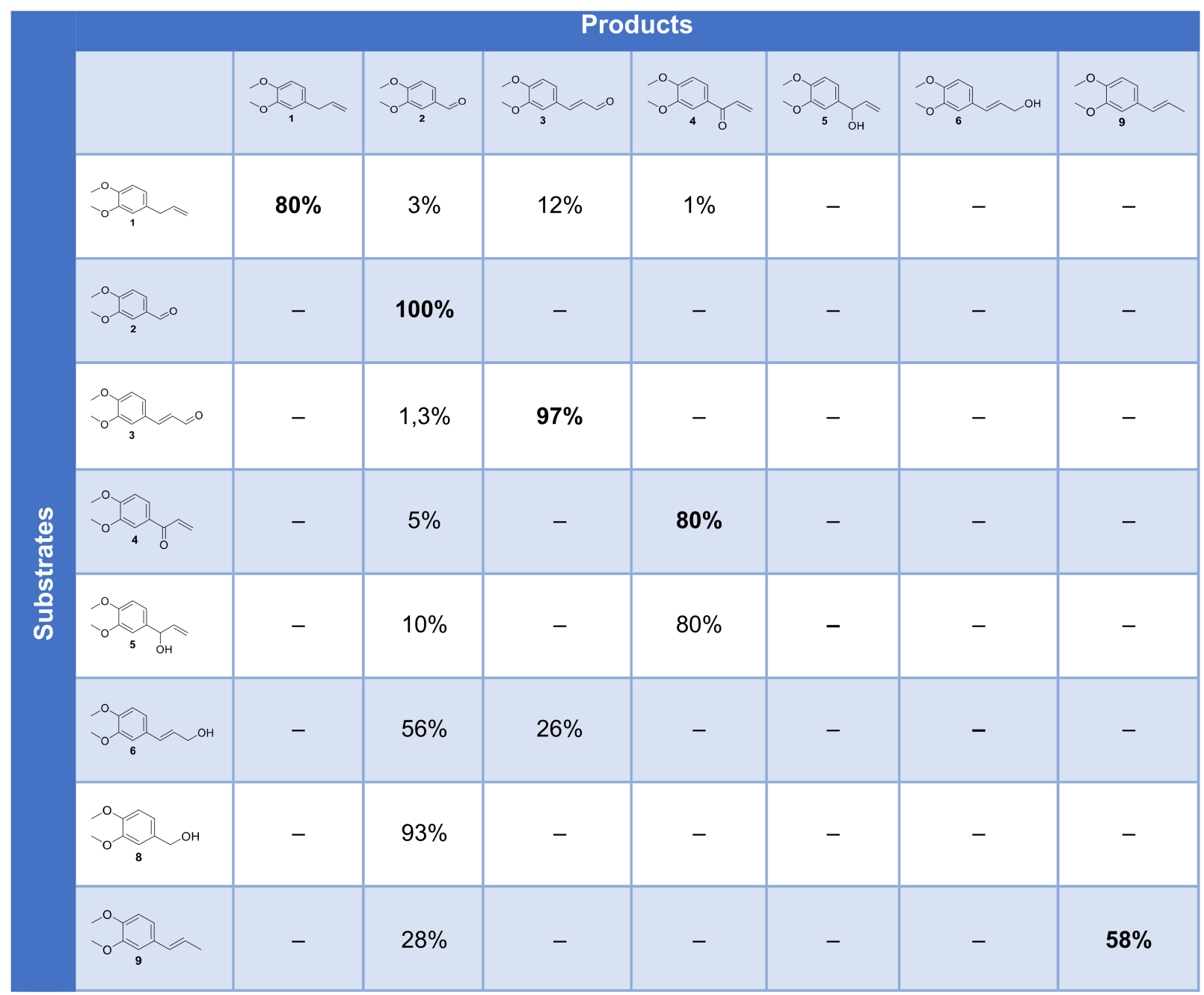

Figure 14. Cross-table of the conversion of substrates and intermediates by the laccase-mediator system.

ME $\mathbf{1}$ is mostly converted into $\mathbf{2 , 3}$ and $\mathbf{4}$. Aldehyde $\mathbf{2}$ is not converted by the laccasemediator system and recovered unchanged, which means that the benzoic derivative is not produced by our system. Compound 3 could not be oxidized by our system, ruling out that it could be an intermediate to 2 . Compound 4 remained mostly unconverted as well. Compound 5 could be oxidized to 4 but only to a limited extent oxidized to 2 , which also rules out this pathway. Compound $\mathbf{6}$ was predominantly oxidized to 2 upon oxidative cleavage and to $26 \%$ of 3 . Compound 8 could be oxidized to 2 almost quantitatively, and compound 9 was partially oxidized to 2 by cleavage.

Considering the data obtained from intermediates reactivity, a proposed mechanism was elaborated (Figure 15). ME $\mathbf{1}$ is oxidized at the benzylic position to 5, or both concomitantly isomerized and oxidized to 6 . Then, the oxidation of the alcohol function into aldehyde 3 is observed, or a direct oxidative cleavage to 2 happens. 5 could be oxidized to 4 , and these two last compounds could contribute to the formation of 2 by oxidative cleavage. 


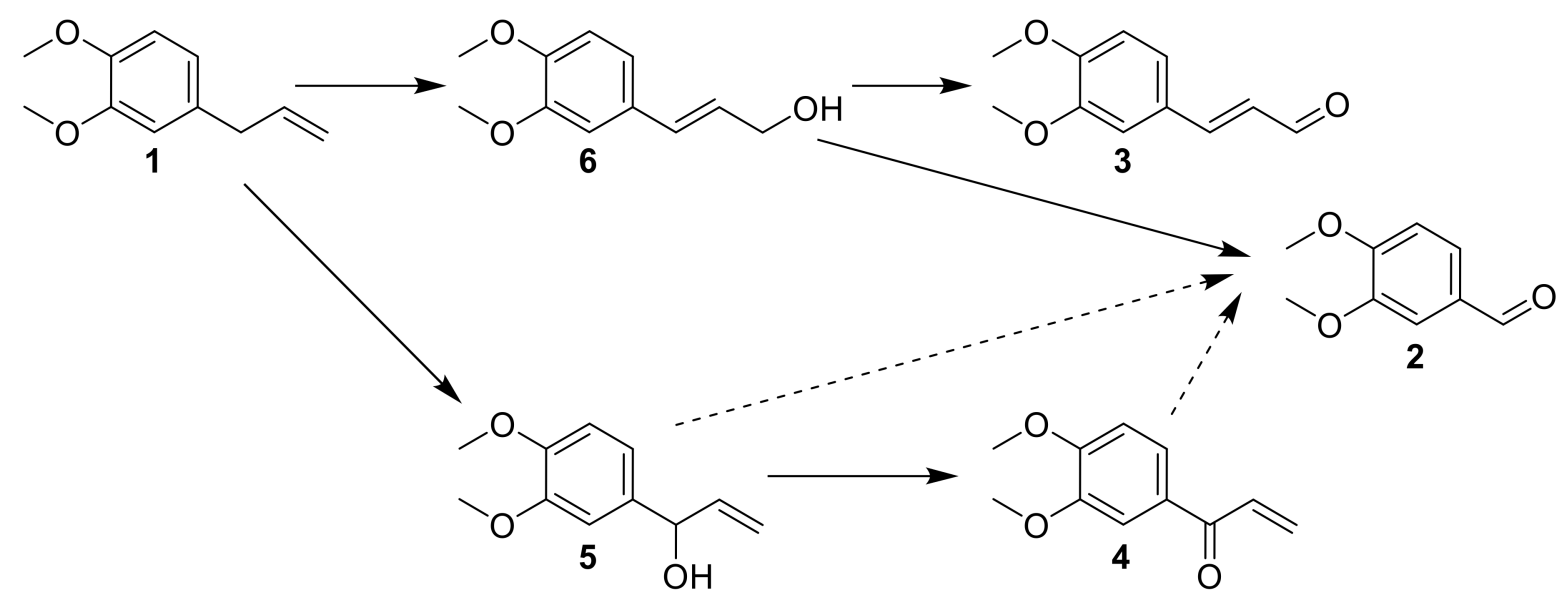

Figure 15. The proposed mechanism after data interpretation from intermediates reaction.

\subsection{Scope and Limitations on Various Allylbenzene Derivatives}

The reactivity of allylbenzene derivatives was investigated using commercially available substrates. Besides allylbenzene 11, substituents on the benzenic ring exhibiting electron-withdrawing or electron-donating effects, such as 1-allyl-4-(dimethylamino) benzene 12, 1-allyl-4-methoxybenzene 13, 1-allyl-2-methoxybenzene 14, 1-allyl-4(trifluoromethyl) benzene 15, eugenyl acetate 16, allylpentafluorobenzene 17, anethol $\mathbf{1 8}$, isoeugenyl acetate 19 and dillapiole 20, were also tested.

Selectivity in terms of oxidation products was examined for various electronic effects (see SI). No clear trend could be identified, and methyl eugenol $\mathbf{1}$ finally appeared as exhibiting the best compromise between the overall electron density and electronic effects.

\section{Conclusions}

The oxidation of allylbenzene derivatives by laccases and laccase-mediator systems was studied with a strong focus on methyl eugenol as a model substrate. The reaction was found to be quite slow, but total conversion could be obtained upon sequential addition of either laccase or a mediator. The oxidation proceeded by a concerted isomerization/hydroxylation of the propenyl side chain followed by two pathways, the former leading to cinnamaldehyde derivatives by further oxidation, and the latter to benzaldehyde derivatives by oxidative cleavage in a mild chemoenzymatic equivalent of ozonolysis. Alternatively, allylic hydroxylation could also be observed, marginally leading to cleavage products as well. The scope of the reaction was examined and was found to be dependent on substitution patterns and electronic effects; the best results being obtained with electron-rich methyl eugenol.

Supplementary Materials: The following are available online. Detailed spectral data, procedures and NMR spectra.

Author Contributions: S.A. designed the study; M.L. performed the experiments; all authors discussed the results; S.A. and M.L. wrote the article. All authors have read and agreed to the published version of the manuscript.

Funding: This research was funded by CNRS, Université Cote d'Azur, and IFF-LMR.

Institutional Review Board Statement: Not applicable.

Informed Consent Statement: Not applicable.

Data Availability Statement: Not available. 
Acknowledgments: M.L.'s Ph.D. fellowship is co-funded by IFF-LMR and French Région SUD. We are grateful to Thierry Tron and Pierre Rousselot-Pailley (ISM2, France) for a gift of pure laccase expressed in their laboratory and Atsushi Tanaka (Amano Enzyme M120) for a loan of various laccase preparations.

Conflicts of Interest: The authors declare no conflict of interest.

Sample Availability: Samples of the compounds are not available from the authors.

\section{References}

1. Ricci, G.P.; de Faria, E.H.; Marcal, L.; Saltarelli, M.; Calefi, P.S.; Nassar, E.J.; Ciuffi, K.J. Heavy Metals, Synthetic Dyes, and Industrial Oxidation Reactions: Green Alternatives from Materials Chemistry; Luque, R., Ed.; Nova Publishers: New York, NY, USA, 2012; pp. 127-147.

2. Poechlauer, P.; Skranc, W. Innovative oxidation methods in fine chemicals synthesis. Curr. Opin. Drug Discov. Dev. 2002, 5, 1000-1008. [CrossRef]

3. Antoniotti, S.; Duñach, E. Studies on the catalytic oxidation of epoxides to $\alpha$-diketones by $\mathrm{Bi}(0) / \mathrm{O}_{2}$ in DMSO. J. Mol. Catal. A Chem. 2004, 208, 135-145. [CrossRef]

4. Cousin, T.; Chatel, G.; Kardos, N.; Andrioletti, B.; Draye, M. Recent trends in the development of sustainable catalytic systems for the oxidative cleavage of cycloalkenes by hydrogen peroxide. Catal. Sci. Technol. 2019, 9, 5256-5278. [CrossRef]

5. Albanese, D.C.M.; Foschi, F.; Penso, M. Sustainable Oxidations under Phase-Transfer Catalysis Conditions. Org. Process. Res. Dev. 2016, 20, 129-139. [CrossRef]

6. Dong, J.; Fernández-Fueyo, E.; Hollmann, F.; Paul, C.E.; Pesic, M.; Schmidt, S.; Wang, Y.; Younes, S.; Zhang, W. Biocatalytic Oxidation Reactions: A Chemist's Perspective. Angew. Chem. Int. Ed. 2018, 57, 9238-9261. [CrossRef]

7. Monti, D.; Ottolina, G.; Carrea, G.; Riva, S. Redox Reactions Catalyzed by Isolated Enzymes. Chem. Rev. 2011, 111, 4111-4140. [CrossRef]

8. Leonowicz, A.; Edgehill, R.U.; Bollag, J.-M. The effect of $\mathrm{pH}$ on the transformation of syringic and vanillic acids by the laccases of Rhizoctonia praticola and Trametes versicolor. Arch. Microbiol. 1984, 137, 89-96. [CrossRef]

9. Zhang, Y.; Nielsen, J.; Liu, Z. Engineering yeast metabolism for production of terpenoids for use as perfume ingredients, pharmaceuticals and biofuels. FEMS Yeast Res. 2017, 17, 1-11. [CrossRef]

10. Deguerry, F.; Pastore, L.; Wu, S.; Clark, A.; Chappell, J.; Schalk, M. The diverse sesquiterpene profile of patchouli, Pogostemon cablin, is correlated with a limited number of sesquiterpene synthases. Arch. Biochem. Biophys. 2006, 454, 123-136. [CrossRef]

11. Krings, U.; Berger, R.G. Biotechnological production of flavours and fragrances. Appl. Microbiol. Biotechnol. 1998, 49, 1-8. [CrossRef] [PubMed]

12. Pogorevc, M.; Kroutil, W.; Wallner, S.R.; Faber, K. Enantioselective Stereoinversion in the Kinetic Resolution of rac-sec-Alkyl Sulfate Esters by Hydrolysis with an Alkylsulfatase from Rhodococcus ruber DSM 44541 Furnishes Homochiral Products. Angew. Chem. Int. Ed. 2002, 41, 4052-4054. [CrossRef]

13. Lecourt, M.; Antoniotti, S. Chemistry, Sustainability and Naturality of Perfumery Biotech Ingredients. ChemSusChem 2020, 13, 5600-5610. [CrossRef]

14. Cañas, A.; Camarero, S. Laccases and their natural mediators: Biotechnological tools for sustainable eco-friendly processes. Biotechnol. Adv. 2010, 28, 694-705. [CrossRef] [PubMed]

15. Witayakran, S.; Ragauskas, A.J. Synthetic Applications of Laccase in Green Chemistry. Adv. Synth. Catal. 2009, 351, 1187-1209. [CrossRef]

16. Sheldon, R.A.; Brady, D. Broadening the Scope of Biocatalysis in Sustainable Organic Synthesis. ChemSusChem 2019, 12, $2859-2881$. [CrossRef]

17. Morozova, O.V.; Shumakovich, G.P.; Shleev, S.; Yaropolov, Y.I. Laccase-mediator systems and their applications: A review. Appl. Biochem. Microbiol. 2007, 43, 523-535. [CrossRef]

18. Fabbrini, M.; Galli, C.; Gentili, P. Comparing the catalytic efficiency of some mediators of laccase. J. Mol. Catal. B Enzym. 2002, 16, 231-240. [CrossRef]

19. Fåhraeus, G.; Ljunggren, H. Substrate specificity of a purified fungal laccase. Biochim. Biophys. Acta 1961, 46, 22-32. [CrossRef]

20. Morozova, O.V.; Shumakovich, G.P.; Gorbacheva, M.A.; Shleev, S.V.; Yaropolov, A.I. “Blue” laccases. Biochem. Mosc. 2007, 72, 1136-1150. [CrossRef]

21. Niku-Paavola, M.-L.; Viikari, L. Enzymatic oxidation of alkenes. J. Mol. Catal. B Enzym. 2000, 10, 435-444. [CrossRef]

22. Majcherczyk, A.; Johannes, C.; Hüttermann, A. Oxidation of Polycyclic Aromatic Hydrocarbons (PAH) by Laccase of Trametes versicolor. Enzym. Microb. Technol. 1998, 22, 335-341. [CrossRef]

23. Ibrahim, V.; Mendoza, L.; Mamo, G.; Hatti-Kaul, R. Blue laccase from Galerina sp.: Properties and potential for Kraft lignin demethylation. Process. Biochem. 2011, 46, 379-384. [CrossRef]

24. Aracri, E.; Colom, J.F.; Vidal, T. Application of laccase-natural mediator systems to sisal pulp: An effective approach to biobleaching or functionalizing pulp fibres? Bioresour. Technol. 2009, 100, 5911-5916. [CrossRef] [PubMed]

25. Camarero, S.; Ibarra, D.; Martínez, Á.T.; Romero, J.; Gutiérrez, A.; del Río, J.C. Paper pulp delignification using laccase and natural mediators. Enzym. Microb. Technol. 2007, 40, 1264-1271. [CrossRef] 
26. Stoilova, I.; Dimitrova, G.; Angelova, G.; Krastanov, A. Biodegradation of phenol, catechol and 2, 4-dichlorophenol at higher initial inhibitory concentrations by Trametes versicolor 1 in a "fed-batch" process. Bulg. J. Agric. Sci. 2017, 23, 988-993.

27. Bollag, J.M.; Chu, H.-L.; Rao, M.A.; Gianfreda, L. Enzymatic Oxidative Transformation of Chlorophenol Mixtures. J. Environ. Qual. 2003, 32, 63-69. [CrossRef]

28. Riva, S. Laccases: Blue enzymes for green chemistry. Trends Biotechnol. 2006, 24, 219-226. [CrossRef]

29. Yao, B.; Kolla, P.; Koodali, R.; Balaranjan, S.; Shrestha, S.; Smirnova, A. Laccase-Natural mediator systems for "green" synthesis of phenolic monomers from alkali lignin. Sustain. Energy Fuels 2017, 1, 1573-1579. [CrossRef]

30. Smith, R.; Adams, T.; Doull, J.; Feron, V.; Goodman, J.; Marnett, L.; Portoghese, P.; Waddell, W.; Wagner, B.; Rogers, A.; et al. Safety assessment of allylalkoxybenzene derivatives used as flavouring substances-Methyl eugenol and estragole. Food Chem. Toxicol. 2002, 40, 851-870. [CrossRef]

31. Johnson, J.D.; Abdo, K.M. Methyleugenol in the diet: Toxic and pathological aspects. Rev. Food Nutr. Toxic. 2005, 3, 1-60.

32. Auerbach, S.S.; Shah, R.R.; Mav, D.; Smith, C.S.; Walker, N.; Vallant, M.K.; Boorman, G.A.; Irwin, R.D. Predicting the hepatocarcinogenic potential of alkenylbenzene flavoring agents using toxicogenomics and machine learning. Toxicol. Appl. Pharmacol. 2010, 243, 300-314. [CrossRef]

33. FDA. Available online: https://www.fda.gov/food/cfsan-constituent-updates/fda-removes-7-synthetic-flavoring-substancesfood-additives-list (accessed on 30 September 2021).

34. European Commission. Opinion on Fragrance Allergens in Cosmetic Products; European Commission: Brussels, Belgium, 2012; p. 334.

35. European Commission. Opinion of the Scientific Committee on Food on Methyleugenol (4-Allyl-1,2-dimethoxybenzene); European Commission: Brussels, Belgium, 2001.

36. Baba, M.; Yamada, K.-I.; Ito, M. Cloning and Expression of a Perilla frutescens Cytochrome P450 Enzyme Catalyzing the Hydroxylation of Phenylpropenes. Plants 2020, 9, 577. [CrossRef]

37. Jeurissen, S.M.F.; Punt, A.; Boersma, M.G.; Bogaards, J.J.P.; Fiamegos, Y.C.; Schilter, B.; van Bladeren, P.J.; Cnubben, N.H.P.; Rietjens, I.M.C.M. Human Cytochrome P450 Enzyme Specificity for the Bioactivation of Estragole and Related Alkenylbenzenes. Chem. Res. Toxicol. 2007, 20, 798-806. [CrossRef] [PubMed]

38. Voda, K.; Boh, B.; Vrtačnik, M.; Pohleven, F. Effect of the antifungal activity of oxygenated aromatic essential oil compounds on the white-rot Trametes versicolor and the brown-rot Coniophora puteana. Int. Biodeterior. Biodegrad. 2003, 51, 51-59. [CrossRef]

39. Burkey, J.L.; Sauer, J.-M.; McQueen, C.A.; Sipes, I.G. Cytotoxicity and genotoxicity of methyleugenol and related congeners-A mechanism of activation for methyleugenol. Mutat. Res. Fund. Mol. M 2000, 453, 25-33. [CrossRef]

40. Llevot, A.; Grau, E.; Carlotti, S.; Grelier, S.; Cramail, H. Selective laccase-catalyzed dimerization of phenolic compounds derived from lignin: Towards original symmetrical bio-based (bis) aromatic monomers. J. Mol. Catal. B Enzym. 2016, 125, 34-41. [CrossRef]

41. Qi, Y.-B.; Wang, X.-L.; Shi, T.; Liu, S.; Xu, Z.-H.; Li, X.; Shi, X.; Xu, P.; Zhao, Y.-L. Multicomponent kinetic analysis and theoretical studies on the phenolic intermediates in the oxidation of eugenol and isoeugenol catalyzed by laccase. Phys. Chem. Chem. Phys. 2015, 17, 29597-29607. [CrossRef]

42. Adelakun, O.E.; Kudanga, T.; Green, I.R.; le Roes-Hill, M.; Burton, S.G. Enzymatic modification of 2,6-dimethoxyphenol for the synthesis of dimers with high antioxidant capacity. Process. Biochem. 2012, 47, 1926-1932. [CrossRef]

43. Xing, W.; Yin, M.; Lv, Q.; Hu, Y.; Liu, C.; Zhang, J. Oxygen Solubility, Diffusion Coefficient, and Solution Viscosity. In Rotating Electrode Methods and Oxygen Reduction Electrocatalysts; Xing, W., Yin, G., Zhang, J., Eds.; Elsevier: Amsterdam, The Netherlands, 2014; pp. 1-31.

44. Ramilijaona, J.; Raynaud, E.; Bouhlel, C.; Sarrazin, E.; Fernandez, X.; Antoniotti, S. Enzymatic Modification of Palmarosa Essential Oil: Chemical Analysis and Olfactory Evaluation of Acylated Products. Chem. Biodivers. 2013, 10, 2291-2301. [CrossRef] 